\title{
Vrij verkeer
}

\section{Regulering van toeristische verhuur: grenzen en mogelijkheden}

\author{
De gevolgen van het arrest Cali Apartments voor de Nederlandse rechtspraktijk
}

\author{
Mr. dr. M.R. Botman*
}

In deze bijdrage wordt aan de hand van het arrest Cali Apartments onderzocht welke ruimte de Europese Dienstenrichtlijn laat om toeristische verhuur van woonruimte te reguleren. In dit licht wordt tevens de Wet toeristische verhuur besproken.

Hv7 22 september 2020, gevoegde zaken C-724/18 en C-727/18, ECLI:EU:C:2020:743 (Cali Apartments en $H X)$.

\section{Inleiding}

Door de opkomst van digitale platforms als Airbnb en booking.com is de toeristische verhuur van woonruimte het afgelopen decennium flink toegenomen. ${ }^{1}$ Grootschalige verhuur van woonruimte aan toeristen kan de leefbaarheid van de woonomgeving aantasten en de lokale woningmarkt verstoren, waardoor de schaarste aan woonruimte verergert. Overheden zoeken dan ook naar mogelijkheden om deze vorm van verhuur te reguleren. Daarbij rijst de vraag hoe dergelijke regulering zich verhoudt tot de Europese Dienstenrichtlijn (Drl). ${ }^{2}$ Deze richtlijn beoogt de vrijheid van vestiging van dienstverrichters en het vrije dienstenverkeer te vergemakkelijken en onnodige belemmeringen voor dienstverrichters op te heffen.

In deze bijdrage onderzoek ik aan de hand van het arrest Cali Apartments onder welke voorwaarden de Diensten-

* Mr. dr. M.R. (Marleen) Botman is senior advocaat bij Pels Rijcken en verbonden aan de Vrije Universiteit Amsterdam.

1. Kamerstukken I/ 2019/20,35353, nr. 3, p. 2.

2. Richtlijn 2006/123/EG van het Europees Parlement en de Raad van 12 december 2006 betreffende diensten op de interne markt (PbEU 2006, L 376/36-68). richtlijn ruimte laat om toeristische verhuur te reguleren. ${ }^{3}$

Daarnaast bespreek ik de praktische gevolgen van het arrest voor de Nederlandse rechtspraktijk. Dit betreft in het bijzonder de toepassing van de Wet toeristische verhuur (hierna: de Wet), die strekt tot wijziging van de Huisvestingswet 2014. ${ }^{4}$ Deze Wet biedt met ingang van 1 januari 2021 aan gemeenten een viertal instrumenten om ongewenste effecten van toeristische verhuur te voorkomen en bestrijden.

\section{De zaak Cali Apartments}

Een vergunning- en compensatieplicht voor wijziging woonbestemming

Het Franse Wetboek Bouw en Woningen (WBW) bepaalt in artikel L. 631-7 dat in gemeenten met meer dan 200.000 inwoners wijzigingen van het gebruik van woonruimte onderworpen zijn aan een voorafgaande vergunning. Dit artikel bepaalt tevens dat het 'herhaaldelijk kortstondig verhuren van gemeubileerde woonruimte aan incidentele klanten die daar niet hun woonplaats kiezen', een dergelijke wijziging is. Anders gezegd, voor het wijzigingen van het gebruik van woonruimte om deze (tijdelijk) te verhuren aan toeristen, is op grond van de nationale regeling een vergunning vereist.

De vergunningplicht wordt uitgevoerd op gemeentelijk niveau. De nationale regelgeving biedt daarbij ruimte aan gemeenten om per wijk te bepalen onder welke voorwaarden de vergunning wordt verleend. Deze voorwaarden moeten worden vastgesteld in het licht van de doelstelling van sociale diversiteit en rekening houdend

3. HvJ 22 september 2020, gevoegde zaken C-724/18 en C-727/18, ECLI:EU:C:2020:743 (Cali Apartments en HX).

4. Stb. 2020, 460; Stb. 2020, 566. 
met de kenmerken van de woningmarkt en de noodzaak te voorkomen dat de woningnood nog groter wordt. Zo nodig kunnen de gemeenten een compensatie eisen in de vorm van een bijkomende, gelijktijdige verbouwing van onroerend goed zonder woonbestemming tot woonruimte (compensatieplicht). Aan eenieder die in strijd handelt met de vergunningplicht of de gestelde voorwaarden, kan een geldboete worden opgelegd van $€ 25.000$.

\section{Het geschil en de prejudiciële vragen}

Ter uitvoering van het WBW heeft de stad Parijs een reglement vastgesteld waarin de voorwaarden voor een vergunning tot wijziging van het gebruik van woonruimte zijn opgenomen, waaronder een compensatieplicht. De gemeente Parijs stelt onder meer eisen aan de oppervlakte van de te compenseren ruimte (kwantum).

Cali Apartments en HX zijn beide eigenaar van een eenkamerflat in Parijs. Zij verhuren deze appartementen via Airbnb zonder dat zij daarvoor een vergunning hebben. De strafrechter heeft hen zowel in eerste als in tweede aanleg veroordeeld tot betaling van een geldboete van $€ 15.000$ wegens overtreding van artikel L. 631-7 WBW. In het cassatieberoep bij de Cour de cassation (de hoogste rechter in burgerlijke en strafzaken in Frankrijk) stellen zij dat de vergunningplicht en de vergunningsvoorwaarden in strijd zijn met de Dienstenrichtlijn. De Cour de cassation betwijfelt echter of de wetgeving wel onder de Dienstenrichtlijn valt en stelt prejudiciële vragen aan het Hof van Justitie. Samengevat gaat het om de volgende vragen: 5

1. Is de Dienstenrichtlijn van toepassing op nationale wetgeving die betrekking heeft op het herhaaldelijk kortstondig, ook niet-beroepsmatig, verhuren van gemeubileerde woonruimte?

2. Zo ja, vormt de nationale regeling een 'vergunningstelsel' dat moet worden getoetst aan artikel 9 tot en met 13 Dienstenrichtlijn of een 'vereiste' dat moet worden getoetst aan artikel 14 en 15 Dienstenrichtlijn?

3. Indien de nationale regeling een vergunningstelsel vormt, is deze in overeenstemming met de vereisten zoals neergelegd in artikel 9 en 10 Dienstenrichtlijn?

\section{Valt een regeling die ziet op niet-beroepsmatige verhuur van woonruimte onder de Dienstenrichtlijn?}

Om te bepalen of nationale wetgeving onder de Dienstenrichtlijn valt, dient onderscheid te worden gemaakt tussen (1) de activiteit waarop de regeling betrekking heeft en (2) de regeling zelf. ${ }^{6}$

5. Zie voor een volledige weergave van de vragen Cali Apartments en HX, punt 26.

6. Cali Apartments en HX, punt 32; zie art. 2 en 3 Drl.

\section{Ad (1) De activiteit}

Het Hof van Justitie begint het arrest met de kwalificatie van de activiteit en stelt vast dat het verhuren van vastgoed een 'dienst' is in de zin van artikel 4 punt 1 van de Dienstenrichtlijn. Het maakt daarbij geen verschil of deze dienst wordt verricht door een rechtspersoon of een natuurlijk persoon. ${ }^{7}$ Het enkele feit dat de regeling mogelijkerwijs ook van toepassing is op activiteiten die van de werkingssfeer van de Dienstenrichtlijn zijn uitgesloten, zoals het omvormen van een woning voor huisvesting van daklozen of vluchtelingen (art. 2 lid 2 onder $\mathrm{j}$ Drl), maakt niet dat de regeling in zijn geheel buiten de werkingssfeer van de Dienstenrichtlijn valt. Een dergelijke opvatting zou, aldus het Hof van Justitie, afbreuk doen aan de nuttige werking van de richtlijn. ${ }^{8}$

\section{Ad (2) De regeling}

Nadat is vastgesteld dat de activiteit onder de Dienstenrichtlijn valt, komt de vraag aan de orde of de regeling zelf is uitgesloten van de werkingssfeer. Ierland had aangevoerd dat dit niet het geval was, gelet op het bepaalde in overweging 9. ${ }^{9}$ Dit betoog volgt het Hof van Justitie echter niet.

In overweging 9 staat dat de Dienstenrichtlijn

'alleen van toepassing [is] op eisen met betrekking tot de toegang tot of de uitoefening van een dienstenactiviteit', zodat zijn uitgesloten 'eisen zoals (...) regels betreffende de ontwikkeling of het gebruik van land, voorschriften inzake ruimtelijke ordening en stedenbouw (...) die de dienstenactiviteit niet specifiek regelen of daarop specifiek van invloed zijn, maar die de dienstverrichters bij de uitvoering van hun economische activiteit in acht dienen te nemen op dezelfde wijze als natuurlijke personen die als particulier handelen.'

Onder verwijzing naar het arrest Visser Vastgoed herhaalt het Hof van Justitie dat deze overweging aldus moet worden uitgelegd dat de Dienstenrichtlijn niet van toepassing is op eisen die het vrij verkeer niet beperken. ${ }^{10}$ Een eis vormt geen beperking als deze de toegang tot of de uitoefening van een dienstenactiviteit niet specifiek regelt of daarop specifiek van invloed is, maar door dienstverrichters in acht moet worden genomen bij het verlenen van de dienst op dezelfde wijze als door personen die handelen als particulier. ${ }^{11}$ Het Hof van Justitie concretiseert dit criterium vervolgens: enkel administratieve formaliteiten, eisen en voorschriften die specifiek een dienstenactiviteit regelen, vallen binnen de werkingssfeer van de richtlijn. ${ }^{12}$

Het Hof van Justitie stelt vast dat de Franse regeling weliswaar betrekking heeft op ruimtelijke ordening en

\footnotetext{
Cali Apartments en HX, punt 34; zie ook art. 4 punt 2 Drl. Cali Apartments en HX, punt 39.

Conclusie A-G M. Bobek 2 april 2020, gevoegde zaken C-724/18 en C-727/18, ECLI:EU:C:2020:251 (Cali Apartments en X), punt 39.

10. HvJ 30 januari 2018, gevoegde zaken C-360/15 en C-31/16, ECLI:EU:C:2018:44 (X en Visser Vastgoed), punt 123.

11. Cali Apartments en $H X$, punt 40

12. Cali Apartments en $H X$, punt 41.
} 
stedenbouw, maar dat de regeling niet 'op iedereen zonder onderscheid van toepassing is'. De regeling is specifiek van toepassing op personen die hun woning kortstondig al dan niet beroepsmatig willen verhuren. ${ }^{13}$ Dit makkt dat de regeling onder de Dienstenrichtlijn valt.

\section{Vergunningstelsel of eis?}

In antwoord op de tweede vraag van de Cour de cassation concludeert het Hof van Justitie dat de Franse regeling moet worden beschouwd als een vergunningstelsel in de zin van artikel 4 punt 6 Drl. ${ }^{14}$ De regeling verplicht personen die onroerend goed willen verhuren om een procedure te volgen waarbij zij bij een bevoegde instantie stappen moeten ondernemen om een formele beslissing te verkrijgen om een bepaalde dienstenactiviteit te mogen uitoefenen. Dit betekent dat het stelsel moet voldoen aan artikel 9 en 10 Drl.

\section{Welke voorwaarden stellen artikel 9 en 10 Drl?}

\section{Tweefasentoets}

Om te beoordelen of een regeling voldoet aan deze bepalingen moet, aldus het Hof van Justitie, eerst worden onderzocht of de invoering van het stelsel als zodanig gerechtvaardigd is (art. 9 Drl), en dient daarna te worden gekeken naar de voorwaarden die gelden voor de afgifte van de vergunning (art. $10 \mathrm{Drl}) .{ }^{15}$ Het betreft dus een tweefasentoets.

Artikel 9 lid 1 Drl bepaalt dat een vergunningstelsel alleen geoorloofd is als (a) dit stelsel niet-discriminatoir is, (b) het gerechtvaardigd wordt door een dwingende reden van algemeen belang en (c) de met dit stelsel nagestreefde doelstelling niet door een minder beperkende maatregel kan worden bereikt, met name omdat een controle achteraf te laat zou komen om werkelijk doeltreffend te zijn. Daarnaast moeten de vergunningsvoorwaarden voldoen aan de criteria in artikel 10 lid 2 Drl, die moeten beletten dat een bevoegde instantie haar beoordelingsbevoegdheid op willekeurige wijze uitoefent. Vergunningsvoorwaarden moeten (a) niet-discriminatoir zijn, (b) gerechtvaardigd worden door een dwingende reden van algemeen belang, (c) evenredig zijn met die reden van algemeen belang, (d) duidelijk en ondubbelzinnig zijn, (e) objectief zijn, (f) vooraf openbaar bekendgemaakt worden en $(\mathrm{g})$ transparant en toegankelijk zijn.

\section{Toets vindt plaats op nationaal én gemeentelijk} niveau

Een complicerende factor hierbij is dat de Franse vergunningplicht voor het wijzigen van het gebruik van woonruimte weliswaar op nationaal niveau is vastgesteld, maar dat de vergunningsvoorwaarden op gemeen-

\footnotetext{
13. Cali Apartments en $H X$, punt $42-45$.

14. Cali Apartments en $H X$, punt 46-53.

15. Cali Apartments en $H X$, punt 58.
}

telijk niveau - binnen de kaders van de nationale regeling - worden bepaald. De prejudiciële vragen zien uitsluitend op de regeling op nationaal niveau. Gelet hierop hebben verschillende lidstaten betoogd dat voor de beoordeling van de nationale regeling artikel 10 Drl niet relevant is. ${ }^{16}$ Het Hof van Justitie gaat hier niet in mee.

In de nationale regeling zijn namelijk criteria geformuleerd voor de wijze waarop op gemeentelijk niveau kan worden bepaald onder welke voorwaarden een vergunning wordt verleend. Zowel dit kader als de wijze waarop deze voorwaarden moeten worden toegepast in de praktijk moeten worden getoetst aan artikel 10 Drl. De nationale regeling dient dus zowel aan artikel 9 als aan artikel 10 Drl te worden getoetst. ${ }^{17}$ Het reglement dat is vastgesteld door de stad Parijs ligt in casu niet voor. Het Hof van Justitie gaat dus niet in op de vraag of het reglement in overeenstemming is met artikel 10 Drl.

\section{Is de vergunningplicht verenigbaar met artikel 9 Drl?}

De vraag van de Cour de cassation of de Franse regeling in overeenstemming is met artikel 9 lid 1 onder b en $\mathrm{c}$ Drl beantwoordt het Hof van Justitie bevestigend.

Bestrijding van woningtekort vormt dwingende reden van algemeen belang (art. 9 lid 1 onder $b$ Drl)

De Franse regelgeving beoogt het tekort aan huurwoningen te bestrijden teneinde een antwoord te bieden op de verslechtering van de voorwaarden voor toegang tot huisvesting en op de toename van de krapte op de vastgoedmarkt door de slechte marktwerking te verbeteren, eigenaren en huurders te beschermen en de vergroting van het woningaanbod mogelijk te maken onder voorwaarden die een evenwichtig grondgebruik respecteren. Het Hof van Justitie oordeelt dat deze doelstelling een dwingende reden van algemeen belang vormt ${ }^{18}$ en verwijst in dit verband naar de rechtspraak waarin de bescherming van stedelijk milieu en doelstellingen van sociaal beleid reeds als zodanig zijn erkend. ${ }^{19}$

Vergunningplicht is evenredig (art. 9 lid 1 onder c Drl)

Het Hof van Justitie acht de vergunningplicht bovendien evenredig met het beoogde doel om het tekort aan huurwoningen te bestrijden, nu dit doel niet met minder beperkende maatregelen kan worden bereikt. Het Hof van Justitie noemt hiertoe een aantal relevante

\footnotetext{
6. Conclusie A-G, Cali Apartments en HX, punt 76 en 77 .

17. Cali Apartments en $H X$, punt 59 en 61.

18. Cali Apartments en $H X$, punt 66 e.v.

19. Het Hof van Justitie verwijst naar $X$ en Visser Vastgoed, punt 135; HvJ 8 mei 2013, gevoegde zaken C-197/11 en C-203/11, ECLI:EU:C: 2013:288 (Libert e.a.), punt 50-52 en HvJ 1 oktober 2009, zaak C-567/07, ECLI:EU:C:2009:593 (Woningstichting Sint Servatius), punt 30.
} 
gezichtspunten. ${ }^{20}$ De nationale regeling is materieel beperkt tot het verhuren van onroerende goederen die bestemd zijn voor bewoning. Daarnaast ziet de regeling niet op woningen die de hoofdverblijfplaats van de verhuurder zijn. Verder heeft het vergunningstelsel een beperkte geografische reikwijdte en geldt het slechts voor een beperkt aantal dichtbevolkte gemeenten waar, zoals blijkt uit eerdergenoemde studie, sprake is van verstoringen van de woninghuurmarkt door de toename van herhaalde kortstondige verhuur. Tot slot zou, aldus het Hof van Justitie, een meldingssysteem met sancties ondoeltreffend zijn om het tekort aan woningen voor langdurige verhuur te bestrijden. Een dergelijk systeem zou het immers niet mogelijk maken de aanhoudende, snelle ontwikkeling die dit tekort veroorzaakt onmiddellijk en doeltreffend af te remmen. ${ }^{21}$

\section{Is het nationaal kader verenigbaar met artikel $10 \mathrm{Drl}$ ?}

Het Hof van Justitie toetst vervolgens de vergunningsvoorwaarden aan artikel 10 Drl.

\section{Nationaal kader dient dwingende reden van}

algemeen belang (onder b)

De nationale regeling schrijft voor dat de gemeenten de vergunningsvoorwaarden vaststellen in het licht van de doelstelling van sociale diversiteit en krapte op de woningmarkt. Omdat het doel van de voorwaarden in het verlengde ligt van het vergunningstelsel, moeten ook deze criteria in beginsel worden geacht gerechtvaardigd te zijn door dezelfde dwingende redenen van algemeen belang. ${ }^{22}$ Het expliciet inkaderen op nationaal niveau van de bevoegdheid op gemeentelijk niveau om vergunningsvoorwaarden vast te stellen, kan er dus aan bijdragen dat deze vergunningsvoorwaarden in overeenstemming zijn met artikel 10 lid 2 onder b Drl. ${ }^{23}$

Evenredigheid: geschikt en noodzakelijk (onder c) De verenigbaarheid van de regeling met artikel 10 lid 2 onder c Drl (evenredigheid) spitst zich toe op de compensatieplicht die een gemeente kan opleggen. Het Hof van Justitie acht deze compensatieplicht in beginsel een geschikt instrument om sociale diversiteit, voldoende woningaanbod en behoud van aanvaardbare huurprijzen na te streven, aangezien de nationale regeling de lokale autoriteiten verplicht deze compensatieplicht af te stemmen op de specifieke situatie van de betrokken gemeente en het doel van de regeling. Het instrument is in het bijzonder geschikt voor gemeenten die hard worden getroffen door vastgoedspeculatie ten behoeve van toeristische verhuur. ${ }^{24}$
Dit neemt niet weg dat de compensatieplicht niet verder mag gaan dan noodzakelijk. Het Hof van Justitie geeft in dit verband een aantal criteria mee aan de nationale rechter. ${ }^{25}$

Om te beginnen dient deze na te gaan of de compensatieplicht daadwerkelijk een oplossing biedt voor het tekort aan woningen voor langdurige verhuur. Studies of andere objectieve onderzoeken die dit kunnen aantonen, zijn daarbij bijzonder relevant.

Vervolgens dient de nationale rechter zich ervan te vergewissen dat de nationale regeling de gemeente de mogelijkheid biedt om het kwantum af te stemmen op de situatie van de huurmarkt in de betrokken gemeente. Dit vormt een sterke aanwijzing dat de compensatieplicht passend is.

Daarnaast dient de nationale rechter zich ervan te verzekeren dat het kwantum ook 'verzoenbaar is' met het aanbieden van toeristische verhuur. Het Hof van Justitie licht toe hoe deze 'verzoenbaarheid' dient te worden beoordeeld. De nationale rechter dient er met name rekening mee te houden dat het kortstondig verhuren in de regel veel winstgevender is dan langdurige verhuur. Tegelijkertijd is van belang dat de compensatieplicht niet in de weg staat aan het verhuren van woningen aan huurders die daar wel hun woonplaats kiezen. Deze vorm van verhuur is weliswaar minder rendabel, maar daarvoor geldt geen compensatieplicht. Ten slotte dient de nationale rechter in aanmerking te nemen hoe de compensatieplicht in de praktijk kan worden nagekomen. ${ }^{26} \mathrm{Zo}$ is van belang of de compensatieplicht ook via andere compensatiemechanismen kan worden nagekomen. ${ }^{27}$

Duidelijkheid, ondubbelzinnigheid en objectiviteit (onder d en e)

Cali Apartments en HX hebben aangevoerd dat het begrip 'herhaaldelijk kortstondig verhuur van gemeubileerde woonruimte aan incidentele klanten die daar niet hun woonplaats kiezen' niet voldoet aan de vereisten van duidelijkheid, ondubbelzinnigheid en objectiviteit (art. 10 lid 2 onder d en e Drl).

Het Hof van Justitie zet allereerst uiteen wat deze vereisten inhouden. De vereisten van duidelijkheid en ondubbelzinnigheid houden in dat de vergunningsvoorwaarden voor iedereen eenvoudig te begrijpen moeten zijn. Een dubbelzinnige formulering moet dus worden vermeden. ${ }^{28}$ Het vereiste van objectiviteit strekt ertoe te verzekeren dat vergunningsaanvragen worden beoordeeld op eigen verdiensten, zodat de betrokken partijen de garantie hebben dat hun aanvraag objectief wordt behandeld. Dit betekent dat vergunningsvoorwaarden zodanig moeten worden gepreciseerd dat er geen twijfel mag bestaan over de voorwaarden en verplichtingen en dat de bevoegde instanties de voorwaarden niet willekeurig kunnen toepassen. 
In de nationale regeling ontbreekt deze precisering. Het is volgens het Hof van Justitie echter niet noodzakelijk dat de voorwaarden al in de nationale regeling worden ingevuld of afgebakend met numerieke drempels. Dat mag ook in lagere regelgeving worden gedaan.

De gemeenten zullen dus nader moeten preciseren wanneer sprake is van 'herhaaldelijk kortstondig verhuur van gemeubileerde woonruimte aan incidentele klanten die daar niet hun woonplaats kiezen'. De nationale rechter zal moeten nagaan of deze precisering voldoet aan de vereisten van duidelijkheid, ondubbelzinnigheid en objectiviteit. Het Hof van Justitie acht deze toets 'van wezenlijk belang', met name indien de vraag naar de duidelijkheid van een begrip rijst in het kader van strafrechtelijke procedure. Hierop is het algemene Unierechtelijk beginsel van legaliteit ter zake van strafbare feiten van toepassing. ${ }^{29}$

Voorafgaande bekendmaking, transparantie en toegankelijkheid (onder $\mathrm{f}$ en $\mathrm{g}$ )

Cali Apartments en HX hebben tot slot betoogd dat de nationale regeling niet voldoet aan de criteria dat vergunningsvoorwaarden vooraf bekend zijn gemaakt, transparant en toegankelijk zijn (art. 10 lid 2 onder $f$ en g Drl), omdat de vergunningsvoorwaarden door de gemeenteraden worden bepaald.

Om te beoordelen of an deze criteria wordt voldaan, dient te worden nagegaan of elke eigenaar die een gemeubileerde woonruimte wil verhuren volledig kennis kan nemen van de door de lokale autoriteiten gehanteerde vergunningsvoorwaarden en - eventueel - de compensatieplicht. Dat blijkt het geval, aldus het Hof van Justitie. Op grond van een algemeen wetboek worden de verslagen van de gemeenteraadszittingen van territoriale overheden aangeplakt in het gemeentehuis en bekendgemakt op de website van de betrokken gemeente. $\mathrm{Nu}$ iedere belanghebbende hierdoor gemakkelijk onmiddellijk kan nagaan of er een regeling bestaat die gevolgen kan hebben voor de toegang tot of de uitoefening van de betrokken activiteit, is aan de criteria van voorafgaande bekendmaking, transparantie en toegankelijkheid voldaan.

\section{De gevolgen van het arrest voor de Nederlandse rechtspraktijk}

\section{Vergunningplicht voor particulier die diensten \\ verricht, valt onder de Dienstenrichtlijn}

Het arrest Cali Apartments maakt in de eerste plaats duidelijk dat vergunningstelsels die gericht zijn op toeristische verhuur van woonruimte onder de Dienstenrichtlijn vallen. Dit geldt ook als de betreffende regeling in acht moet worden genomen door particulieren die niet-beroepsmatig hun woning verhuren tegen een vergoeding.

29. HvJ 3 mei 2007, zaak C-303/05, ECLI:EU:C:2007:261 (Advocaten voor de Wereld), punt 49.
Met dit oordeel verduidelijkt het Hof van Justitie overweging 9 van de Dienstenrichtlijn, waarin lijkt te worden uitgegaan van een onderscheid tussen 'de dienstverrichter' enerzijds en 'de particulier' anderzijds. Dit onderscheid is niet (meer) valide. Door de opkomst van de deeleconomie verrichten ook veel particulieren (niet-beroepsmatig) diensten. ${ }^{30} \mathrm{Om}$ te beoordelen of een regeling buiten de werkingssfeer valt, dient de vraag te worden beantwoord of deze regeling 'op iedereen zonder onderscheid' van toepassing is. Daarmee wordt bedoeld dat de regeling op geen enkele manier onderscheid maakt tussen dienstverrichters (waaronder ook particulieren die niet-beroepsmatig diensten verrichten) en personen die geen dienstenactiviteiten verrichten. $\mathrm{Om}$ dit vast te stellen dient te worden gekeken naar het effect van de regeling op de uitoefening van de dienst. ${ }^{31}$

Dienstenrichtlijn laat ruimte voor regulering van toeristische verhuur

Het arrest maakt voorts duidelijk dat de Dienstenrichtlijn ruimte laat voor een vergunningplicht voor toeristische verhuur. Het arrest biedt in dit opzicht een belangrijke houvast aan overheden die een dergelijke vergunningplicht willen introduceren.

Een belangrijke constatering is dat bestrijding van het tekort aan (betaalbare) huurwoningen een dwingende reden van algemeen belang vormt die een vergunningplicht kan rechtvaardigen. Opvallend is dat het Hof van Justitie angeeft bij dit oordeel rekening te hebben gehouden met de door de Franse regering overgelegde studie waaruit blijkt dat toeristische verhuur een aanzienlijk inflatoir effect heeft op de huurprijzen. Doorgaans komt een dergelijke onderbouwing pas aan de orde bij de vraag of de maatregel geschikt is. Kennelijk kan die onderbouwing ook al van belang zijn bij het vaststellen van het beoogde doel. Op basis van dit arrest mag in mijn ogen echter in zijn algemeenheid worden aangenomen dat het bestrijden van het tekort aan huurwoningen een dwingende reden vormt en dat niet ten aanzien van iedere regeling afzonderlijk (nogmaals) hoeft te worden onderbouwd dat toeristische verhuur de huizenprijzen kan opdrijven met als gevolg dat de toegang tot de woning verslechtert en de krapte op de woningmarkt toeneemt. Het Hof van Justitie baseert zijn oordeel primair op eerdere rechtspraak. De verstrekte studie lijkt in zoverre niet van doorslaggevende betekenis te zijn geweest.

Dit laat onverlet dat de uitspraak nog eens bevestigt dat studies en rapporten (wel) van groot belang zijn om te onderbouwen dat een vergunningplicht en de vergunningsvoorwaarden evenredig zijn. ${ }^{32}$ Dit belang kan moeilijk worden onderschat. Dit geldt temeer als sprake is van een voorwaarde die een 'zware' beperking met zich brengt voor dienstverrichters, zoals de verplichting om onttrokken woonruimte te compenseren. Het kan in

30. Conclusie A-G, Cali Apartments en HX, punt 62.

31. Een voorbeeld in de nationale rechtspraak: ABRvS 13 maart 2019, ECLI:NL:RVS:2019:810.

32. Bijvoorbeeld HvJ 4 juli 2019, zaak C-377/17, ECLI:EU:C:2019:562 (Europese Commissie/Duitsland). 
dergelijke gevallen verstandig zijn om voorafgaand aan de invoering het nut en noodzaak hiervan te (laten) onderzoeken.

Het valt op dat het Hof van Justitie bij de toetsing van het vergunningstelsel aan artikel 9 Drl niet ingaat op de vraag of de vergunningplicht geschikt is om het beoogde doel te bereiken. Dit zou een gevolg kunnen zijn van het feit dat dit criterium in dit artikel niet expliciet is opgenomen. De geschiktheidstoets maakt echter wel een vast onderdeel uit van de evenredigheidstoets die het Hof van Justitie gebruikt om beperkingen van het vrij verkeer te beoordelen. ${ }^{33}$ De geschiktheidstoets vindt ook plaats bij de beoordeling van de vergunningsvoorwaarden aan het vereiste van evenredigheid in de zin van artikel 10 lid 2 onder c Drl. ${ }^{34}$ Overheden doen er in mijn ogen dan ook verstandig aan bij de invoering van een vergunningstelsel hoe dan ook aandacht te besteden aan de vraag of wordt voldaan aan het geschiktheidsvereiste. ${ }^{35}$ In dit kader is van belang dat het vergunningstelsel alleen geschikt kan worden geacht, indien het is gebaseerd op een coherent en systematisch beleid dat ertoe zal leiden dat het beoogde doel wordt gerealiseerd.

Verzoenbaarheidstoets wordt toegevoegd, artikel 17 Handvest en 1 EP

Terwijl ten aanzien van de vergunningplicht een deel van de evenredigheidstoets ontbreekt, voegt het Hof van Justitie bij de beoordeling van de compensatieplicht een aspect toe. De nationale rechter dient na te gaan of het kwantum van de compensatie 'verzoenbaar is' met het aanbieden van toeristische verhuur.

Het lijkt erop dat het Hof van Justitie van de nationale rechter verlangt dat deze een 'echte' belangenafweging maakt en zich bij de toetsing van de maatregel aan de Dienstenrichtlijn ook buigt over de evenwichtigheid van de maatregel. Een afweging die ziet op het evenredigheidsbeginsel in stricto sensu wordt niet veel gebruikt. Mogelijk kan hier een link worden gelegd met de belangenafweging die moet worden gemaakt als het gaat om het reguleren van het recht op eigendom zoals neergelegd in artikel 17 Handvest van de grondrechten van de Europese Unie (Handvest) en artikel 1 Eerste Protocol (EP) bij het Europees Verdrag voor de Rechten van de Mens (EVRM). Advocaat-generaal Bobek besteedt in zijn conclusie uitgebreid aandacht aan deze bepalingen. ${ }^{36}$ Woningeigenaren mogen niet buitensporig en onevenredig worden belast. In het verlengde hiervan werpt hij ten aanzien van de compensatieplicht kritische vragen op. ${ }^{37}$ Iemand die over meerdere onroerende goederen beschikt of een projectontwikkelaar is, zal vrij eenvoudig aan de compensaties kunnen voldoen. Maar is de maatregel ook nog evenredig indien een eigenaar die alleen beschikt over een eenkamerflat van $20 \mathrm{~m} 2$ een

33. Bijvoorbeeld HvJ 8 mei 2019, zaak C-230/18, ECLI:EU:C:2019:383 (PI).

34. Zie ook HvJ 4 juli 2019, zaak C-393/17, ECLI:EU:C:2019:563 (Freddy Lucien Magdalena Kirschstein en Thierry Frans Adeline Kirschstein), punt 80.

35. Een voorbeeld waarin de onderbouwing onvoldoende was: ABRvS 3 maart 2021, ECLI:NL:RVS:2021:461.

36. Conclusie A-G, Cali Apartments en HX, punt 86-95.

37. Conclusie A-G, Cali Apartments en HX, punt 127-136 bedrijfspand van dezelfde grootte moet aanschaffen en verbouwen tot een woning? Toeristische verhuur zou niet enkel mogen worden voorbehouden aan projectontwikkelaars. Tegelijkertijd acht de advocaat-generaal het goed denkbaar dat compensatieplichten binnen een gemeentelijke context zodanig kunnen worden ingericht dat deze evenredig zijn. Daarbij is van belang dat - om te komen tot een evenredige uitkomst - voor bepaalde woningen of eigenaren uitzonderingen worden gemaakt. Dit vereist wel dat gemeenten over voldoende speelruimte beschikken om de regeling in zijn geheel evenredig te maken. Dit impliceert ook dat per gemeente vergunningsvoorwaarden kunnen verschillen. Anders gezegd: het ruimte bieden aan maatwerk op gemeentelijk niveau (en dus aan lokale diversiteit), kan bijdragen aan de evenredigheid van een vergunningplicht voor toeristische verhuur van woonruimte. Per gemeente zal moeten worden beoordeeld of wordt voldaan aan de verzoenbaarheidstoets. In toekomstige rechtspraak zal moeten worden bezien of deze toets zich verder ontwikkelt.

\section{De Wet toeristische verhuur in het licht van de Dienstenrichtlijn}

Met ingang van 1 januari 2021 is de Wet toeristische verhuur in werking getreden. ${ }^{38}$ Deze Wet strekt tot wijziging van de Huisvestingswet 2014 (Hv 2014) en voorziet in een viertal instrumenten voor gemeenten om toeristische verhuur in goede banen te leiden en uitwassen te voorkomen. De instrumenten kunnen worden opgenomen in de gemeentelijke huisvestingsverordening. ${ }^{39}$

Om te beginnen kunnen gemeenten degenen die woonruimte aanbieden voor toeristische verhuur verplichten (eenmalig) een registratienummer aan te vragen (art. 23a Hv 2014). Dit nummer moet de verhuurder vervolgens vermelden bij elke advertentie, onder meer op verhuurderplatforms zoals Airbnb. Met deze registratieplicht krijgt de gemeente inzicht in waar, door wie en welke woonruimte wordt angeboden voor toeristische verhuur. In aanvulling op de registratieplicht kan in de huisvestingsverordening worden bepaald dat woonruimte slechts voor een maximaal antal nachten per jaar toeristisch mag worden verhuurd (art. 23b lid 1 Hv 2014). $\mathrm{Om}$ te controleren of aan dit nachtencriterium wordt voldaan, kan in de huisvestingsverordening tevens worden opgenomen dat verhuurders iedere toeristische verhuring moeten melden bij de gemeente (art. 23b lid 2 Hv 2014).

Tot slot kan een gemeente een vergunningplicht voor toeristische verhuur van woonruimte instellen (art. 23c Hv 2014). Indien dat noodzakelijk is, kan worden bepaald dat het antal vergunningen dat in een gebied

38. Stb. 2020, 460; Stb. 2020, 566.

39. Er is aangesloten bij de bestaande systematiek; de gemeenteraad dient eerst in een huisvestingsverordening categorieën van woonruimte aan te wijzen waarvoor de instrumenten kunnen worden ingezet. 
kan worden afgegeven, gemaximeerd is. In dat geval wordt een schaarse vergunning gecreëerd.

Gemeenten kunnen geen gebruik meer maken van artikel $21 \mathrm{Hv}$ 2014, op grond waarvan zij konden bepalen dat het verboden is om zonder een vergunning woonruimte te onttrekken aan de woonvoorraad. ${ }^{40}$

\section{Wat betekent het arrest Cali Apartments voor de toepassing van deze instrumenten?}

\author{
Instrumenten vallen onder toepassingsbereik \\ Dienstenrichtlijn
}

Het arrest Cali Apartments maakt duidelijk dat deze instrumenten vallen onder het toepassingsbereik van de Dienstenrichtlijn. Dit heeft de wetgever bij de totstandkoming van de wet - vooruitlopend op het arrest - overigens al onderkend. ${ }^{41}$ Dit betekent dat bij het vaststellen van de instrumenten moet worden gewaarborgd dat deze verenigbaar zijn met (onder andere) artikel 9 en $10 \mathrm{Drl}$ als het gaat om de vergunningplicht en artikel 14 en 15 Drl als het gaat om de andere instrumenten, zoals het nachtencriterium. De meldplicht in artikel 23b lid 2 Hv 2014 dient mijns inziens te worden aangemerkt als een eis en niet als vergunningstelsel in de zin van de Dienstenrichtlijn. De meldplicht betekent immers niet dat de verhuurder een formeel besluit moet afwachten voordat hij tot verhuur kan overgaan.

Het is, aldus de memorie van toelichting, aan de gemeenteraad om aan de hand van de lokale omstandigheden en met zo veel als mogelijk kwantificeerbare gegevens te onderbouwen dat het in te voeren instrument (1) gerechtvaardigd is om een dwingende reden van algemeen belang, (2) geschikt is om dit doel te realiseren en (3) niet met minder vergaande middelen kan worden bereikt. ${ }^{42}$

\section{Hoe kunnen de instrumenten worden}

gerechtvaardigd?

Het gebruik van de instrumenten door gemeenten is in de Wet op een aantal punten ingekaderd, hetgeen relevant is voor de rechtvaardiging.

In de eerste plaats kunnen de instrumenten op grond van artikel 23a lid $1 \mathrm{Hv} 2014$ slechts om twee redenen worden ingezet: met het oog op (1) het behoud of de samenstelling van de woonruimtevoorraad, of (2) het behoud van de leefbaarheid van de woonomgeving. ${ }^{43}$

40. Art. 51 Huisvestingswet 2014 voorziet in een overgangsregeling.

41. Kamerstukken // 2019/20, 35353, nr. 3, p. 9.

42. Kamerstukken I/ 2019/20, 35353, nr. 3, p. 15.

43. Normaal gesproken kan de gemeenteraad alleen van zijn bevoegdheden in de Huisvestingswet 2014 gebruikmaken indien dat noodzakelijk en geschikt is voor het bestrijden van onevenwichtige en onrechtvaardige effecten van schaarste aan woonruimte (art. 2 Hv 2014). Op grond van de Wet toeristische verhuur kan de gemeenteraad ook een huisvestingsverordening vaststellen indien dat noodzakelijk is met het oog op de leefbaarheid van de woonomgeving. Schaarste aan woonruimte is dus niet vereist.
Bij het toepassen van de instrumenten ligt het dan ook in de rede om het behoud van de leefbaarheid in de woonomgeving en/of het behoud van de woningvoorraad te gebruiken als dwingende redenen van algemeen belang. Deze doelstellingen komen overeen met de Franse wet in het arrest Cali Apartments.

In de tweede plaats komt in de Wet en de memorie van toelichting sterk tot uitdrukking dat als uitgangspunt dient te worden gehanteerd dat het minst vergaande instrument moet worden ingezet om het beoogde doel te realiseren. Voordat een vergunningplicht kan worden ingevoerd, dient bijvoorbeeld eerst de registratieplicht te zijn toegepast (art. 23c lid $1 \mathrm{Hv} 2014$ ). In de toelichting bij de Wet is tevens opgenomen dat de gemeenteraad bij de invoering van een vergunningplicht in het bijzonder moet stilstaan bij de vraag waarom een vergunning ex ante nodig is in plaats van controle achteraf. $^{44}$

Bij de rechtvaardiging van een instrument vormen ook de gezichtspunten die het Hof van Justitie noemt in het arrest Cali Apartments een goed houvast. Het toepassingsbereik van de regeling dient zo beperkt en specifiek mogelijk te zijn. Zo ligt het niet voor de hand om een regeling die beoogt de nadelige gevolgen van toeristische verhuur te verzachten, ook van toepassing te verklaren op langdurige verhuur. Daarnaast dient ook de geografische reikwijdte van de regeling zo veel mogelijk te worden beperkt tot gebieden of wijken waar dit noodzakelijk is, bijvoorbeeld omdat er zich een (nijpend) tekort aan woningen voordoet of omdat de bevolkingsdichtheid hoog is. De regeling dient te worden afgestemd op de lokale omstandigheden, ook als dat tot gevolg heeft dat tussen wijken of gemeenten verschillende regimes ontstaan. Het verdient dan ook aanbeveling om in een gemeentelijke verordening enige flexibiliteit in te bouwen om bepaalde vergunningsvoorwaarden in een specifieke wijk al dan niet toe te passen.

\section{Totaalverbod mogelijk?}

Een interessante vraag is in hoeverre het gemeenten is toegestaan om toeristische verhuur te verbieden. In de memorie van toelichting bij de Wet is aangegeven dat een dergelijk verbod niet snel te rechtvaardigen zal zijn voor het gehele grondgebied van een gemeente omdat er altijd minder vergaande middelen mogelijk zullen zijn, zoals het nachtencriterium. In uitzonderlijke omstandigheden acht de wetgever een dergelijk verbod wel mogelijk. ${ }^{45}$ Hieruit leid ik af dat een verbod in ieder geval tot de mogelijkheden behoort in een wijk waar minder vergaande alternatieven geen soelaas bieden. In toekomstige rechtspraak zal dit zich verder moeten uitkristalliseren.

Geconcludeerd kan worden dat het toepassen van de nieuwe instrumenten die in handen zijn van gemeenten, goed te verenigen zijn met de Dienstenrichtlijn. Het arrest Cali Apartments biedt gemeenten concrete handvatten om hier invulling aan te geven.

44. Kamerstukken I/ 2019/20, 35353, nr. 3, p. 19

45. Kamerstukken I/ 2019/20, 35353, nr. 3, p. 19 en 27-28. 


\section{Slotbeschouwing}

Het arrest Cali Apartments kan worden beschouwd als een nieuw mijlpaalarrest over de toepassing van de Dienstenrichtlijn. Het arrest laat zien dat de Dienstenrichtlijn ruimte laat voor regulering van toeristische verhuur van woonruimte en biedt waardevolle inzichten aan gemeenten die toepassing willen geven aan de bevoegdheden die zij in dit verband hebben gekregen op grond van de Wet toeristische verhuur. Lokaal maatwerk is daarbij een belangrijke voorwaarde evenals het uitgangspunt dat het minst vergaande alternatief wordt gebruikt. Onder welke omstandigheden een verbod op toeristische verhuur kan worden opgelegd, zal in de toekomst moeten blijken.

Maar het belang van het arrest reikt verder dan toeristische verhuur. Het biedt nuttige inzichten als het gaat om regulering van dienstenactiviteiten in zijn algemeenheid. Het Hof van Justitie preciseert hoe kan worden bepaald of een regeling die (ook) ziet op particulieren, onder de werkingssfeer van de Dienstenrichtlijn valt. Het arrest maakt glashelder hoe vergunningstelsels die in medebewind kunnen worden vastgesteld of uitgevoerd, aan artikel 9 en 10 Drl moeten worden getoetst. Ook de concretisering van de criteria voor vergunningsvoorwaarden zijn voor de praktijk zeer welkom. De toekomst zal uitwijzen of de 'verzoenbaarheidstoets', die duidt op een belangenafweging, wordt opgevolgd. 